\title{
Influence of Ethical Leadership and Talent Management on Employee Performance: Does Employee Commitment Matter in Malaysian Hotel Industry?
}

\author{
Muhammad Rajbul Asik bin Abdul Hamid \\ Graduate School of Business, Universiti Sains Malaysia \\ PO Box 11700, Penang, Malaysia \\ E-mail: mohdasiq92@gmail.com \\ Noor Fareen Abdul Rahim \\ Graduate School of Business, Universiti Sains Malaysia \\ PO Box 11700, Penang, Malaysia \\ E-mail: noorfareen@usm.my \\ Yashar Salamzadeh (Corresponding author) \\ Graduate School of Business, Universiti Sains Malaysia \\ PO Box 11700, Penang, Malaysia \\ E-mail: yashar@usm.my
}

Received: May 13, 2020 Accepted: June 15, 2020 Online published: June 28, 2020

doi:10.5296/ijhrs.v10i3.17266

URL: https://doi.org/10.5296/ijhrs.v10i3.17266

\begin{abstract}
Purpose-The purpose of this study is to examine the influences of ethical leadership and talent management on hotel front desk employees' performance. This study also tests the mediating effect of employee commitment in the relationship between ethical leadership, talent management and employee performance. Leader member exchange theory and social exchange theory has been used as the underlying theories for the framework in this study.

Methodology-Data is collected through online questionnaire distributed to front desk employees working in One-star, two- star and three-star hotels around Malaysia particularly in
\end{abstract}


Penang and Kuala Lumpur. 150 usable questionnaires are collected from the targeted respondents. Sample size have been identified using $G$ power software and Partial Least Square (PLS) is used to analyze data.

Findings - The findings of this study show that the ethical leadership does not have significant relationship with employee commitments, while talent management has a positive and significant relationship with employee commitments. This study also confirms the mediating effect of employee commitments between the relationship of talent management and employee performance.

Contribution -The current study contributes towards the body of knowledge by incorporating leader member exchange theory and social exchange theory. This study also contributes by proving the mediating effect of employee commitment in the hotel industry. The study provides information for hotel managers about why and under what circumstances employees perform better.

Keywords: ethical leadership, talent management, employee commitment, employee performance, Malaysia, hotel industry

\section{Introduction}

Nowadays, hotels management have realized that they need to be unique so that they can have more competitive advantage. Sustainability and competitive advantage in the business world are very important to the hotel industry. Therefore, organizations, particularly hotels, have to go through never-ending process of continuous improvement and people dimension is one of the areas that needs improvements. To develop and survive in markets, firms need to focus on their employees as a source of strategic advantage (Wright \& Snell, 2009). The firms' performance also depends on their employees, as they will form teams and work towards their goals (Mukherjee, et el., 2012).

Employee performance is the outcome of what have been achieved at work and is highly depended on the level of individual performance. In the hotel industry, front desk employees are important in welcoming and entertaining hotel guests. The examples of services that are provided by front desk employees are performing all check in and check out tasks, managing online and phone reservation, informing customers about payment method and verifying credit card data. All these services are crucial for the comfort of guests and to ensure their satisfaction. Thus, it is clear why the value of hotel lies on its human resources (Evans \& Lindsay, 2011). Front desk employees need to play their role so that all the works will be efficient and hotel will attract more customers only in this case. For example, if the employee is lagging in providing a service to the customer, the hotel will receive bad review, and this will affect future customers to come to the hotel. Especially nowadays which customers are booking hotels through online platform such as Agoda, Traveloka and other online booking applications, they are free to comment about the services to help other customers to know the level of the services provided by the hotel; either good or bad. The reviews from customers are important for hotels because it reflects the front desk employees' performance to attract and satisfy hotel guests' requests. Hotels with bad rating review will lose customers and revenue. 
Employee commitment is an important factor that can affect employees' performance if firms believe in the importance of talents in becoming an excellent organization (Iles et el., 2010). Employee commitment is a psychological attitude of the employee that enables the employee to identify the goals and values of his or her organization (Peng et al., 2016). Thus, employees are often motivated to pursue aligned interests and remain loyal to the organization (Meyer and Allen, 1991). Commitment is important because it often leads to better job performance (Jaramillo et al., 2005) and thus the competitive advantage for organizations. Employee commitment is critical in the hospitality industry because it results in greater customer satisfaction and loyalty as well as better service quality (Nadiri \& Tanova, 2010). Research done by Robertson and Birch (2010) and Gallup (2013) revealed that only 13 percent of employees worldwide are engaged in their work. Previous studies suggest that employees' lack of engagement to the company tend to be skeptical of any initiative or communication the company offers, and of course, this condition is potentially contagious to other employees (Perrin, 2003; Ellis and Sorensen, 2007; Dernovsek, 2008). Besides affecting employee performance, employee engagement can also be influenced by ethical leadership. According to McBain (2007), the high/low level of employee engagement depends on the leadership. This is also supported by research conducted by Walumbwa and Schaubroeck (2009) that ethical leadership affects employee engagement.

Concern for ethical leadership in the field of business administration emerged in reaction to scandals, corruption and conflicts of interest (Colvin, 2003; Kalshoven, 2010; Kalshoven et al., 2011; Mehta, 2003; Burlea-Schiopoiu, A., \& Mihai, L. S., 2019). Thus, interest in ethics in organizational administration became more pronounced given the need for vigilance in the interests of greater social justice, a value that is highly cherished in the world of organization. Besides, ethical leadership have been considered as a major factor that affects employee performance (Wang, et. el, 2005). Previous studies stated that there is a positive relationship between leadership and employee's performance in achieving firms' goal (Resick, et. el, 2006; Walumbwa \& Shaubroeck, 2009; Zehir \& Erdogan, 2011; Sabir, et. el, 2012; Widani, et el, 2019). A good leader will influence the employee to perform well in their daily work. Moral theory of ethical judgment in the workplace underlies the concept of ethical sensitivity. The special function of this theory is to provide individuals with conceptual guidance for choosing to act in situations when there are conflicting moral claims. According to Rest (1986), moral judgment is based on four dimensions: ethical sensitivity, ethical judgment, ethical motivation, and ethical character. Rest (1986) and Cooper (2006) agree that ethical sensitivity should be recognized as the first step in ethical behavior development whereas Tuana (2007) posits that ethical sensitivity is a key element in moral literacy development, which involves at least three major components:

(1) The ability to determine whether a situation involves ethical issues or not.

(2) Awareness of the moral intensity of the ethical situation; and

(3) The ability to identify the moral virtues or values underlying an ethical situation

Besides ethical leadership, managing organizational workforce is synonymous to managing individual and unique talents to yield desired results. Human capital has been established as 
the most important asset for any organization. It is widely accepted that in the long run, the organization with the best people wins. Proportionate to this observation is the fact that the most pressing concerns of business leaders are those about their people/human capital. The main objective for talent management is to maximize the employee's talent into the firm (Pandita \& Ray, 2018). Hence, this study helps to clarify talent management concept and make it clear that talent management can influence the employees' performance through employee commitment (Mensah, 2015). Employee is one of the main sources of company success. To have a good employee, human resource department needs to select good quality employees who suit with the job offered. A good leader will treat their employees nicely as they are the assets of the company and investing in talent is worth if the employees can generate revenues. According to Dessler (2005), employees' satisfaction and their performance is positively related.

There are crucial issues with relate to talent management in a wider range of organizations and has emerged as a key human resource challenge facing firms in a various industry (Farndale et al., 2010; Scullion et al., 2016). The literature on talent management is not well grounded in research and is dominated by business and consulting firms who lead in advancing a vision on the discourse of talent management (Cascio \& Boudreau, 2016). The academic field of talent management is characterized by limited theoretical and conceptual development and unresolved issues remain over the definition and boundaries of the term talent management (Sparrow et al., 2014; Collings \& Mellahi, 2009). Studies have argued for the need for more conceptual work in the area of talent management (Thunnissen et al., 2013; Sparrow et al., 2014). Organizations face with staff turnover due to reasons such as poor compensation systems, ineffective training programs, lack of promotion, no career path and succession planning, which is all included in the tenet of talent management. A significant amount of the efforts in talent management goes toward managing the talent pool and developing career trajectories of top talent in the firm. This may involve career path planning, setting up pipelines for succession, development programs, and a whole host of other implementable strategies for the high potential and/or high performing employees, as the organization sees fit (Cappelli, 2009).

In this study, hotel industry ranging from one-star to three-star hotels have been selected and we try to find an answer to the question if ethical leadership and talent management can influence employee performance through the mediating role of employee commitment or not (Nejati et al., 2019). The need for hotel operators to pay more attention in handling their guests has become crucial to stay competitive in the hotel industry, as customer expectations are changing. It is imperative for hotel operators to continue incorporating new service elements into their service delivery. Hotel operators should anticipate that different guests always come with various levels of service expectations (Cheng, Gan, Imrie \& Mansouri, 2018). International tourism has developed exponentially as compared to world trade, representing 7 per cent of the world's goods and services export in 2015; an increase of 1 per cent compared to 2014. In 2015, international tourist arrivals amounted to 1,186 million, an increase of 52 million from 2014. This is at a constant increase of a minimum of 4 per cent since 2010 (UNWTO, 2017).

Therefore, hoteliers must understand the importance of employees' performance that could 
lead to greater business performance. Penang and Kuala Lumpur are the major cities in Malaysia that always has a vast number of tourists and this number increases each year. These are the fastest growing regions in Malaysia. It is impossible to build more hotels due to this increasing number of tourists, but several actions need to be taken to serve the tourists with the limited capacity of hotels. Hence, with a planned action and strategy, the hotel industry can contribute more to the Malaysia's GDP (Kara, 2017).

Based on the existing studies, we could not find any research that integrates the relationship between ethical leadership, employee commitment and talent management on employee performance in a research model. Previous studies have identified the influence of ethical leadership, employee commitment and talent management in improving employee performance in separate research models, so there is a gap for further research, considering all these factors together. The purpose of this study is to examine the influence of ethical leadership and talent management on employee performance and it investigates the mediating role of employee commitment in hotel industry. This research is necessary to justify whether ethical leadership and talent management have an influence on employee performance or not. Thus, this study targeted one to three star hotels' front desk employees around Penang and Kuala Lumpur. These hotels are considered as budget hotels due to the low pricing as compared to high-end hotels. Many local and foreign tourists would prefer these hotels due to the pricing and their strategic locations. Other interesting points to ponder are the issues of ethical leadership and talent management of these hotels. It is worth to investigate the perceptions of the front desk employees in terms of the ethical leadership and the talent management in their workplace. Penang and Kuala Lumpur are chosen because they are many tourists visiting both cities. Besides, Penang is known as Heritage City while Kuala Lumpur is the Capital City of Malaysia (Ministry of Tourism Malaysia, 2017).

\section{Literature Review and Hypotheses}

\subsection{Employee Performance}

Employees are contributing to the organizations directly or indirectly. Indirect employees are individuals that are not involved in making product or providing services but they can make the service/production more effective and efficient. On the other hand, the direct employees are involved in end-to-end process in service/production directly.

Effective employees have a combination of good skill sets and efficient work. In an organization, managers need to be aware of the factors that can affect the employees' performance and should always look forward to improve it (Mathis \& Jackson 2009). Many organizations do not use the correct and systematic way to evaluate the employees' performance, hence the evaluation is inefficient, and the result is not aligned with the organization's objective (Ahmed, Ineen, \& Azeem, 2013). To get the best performance from employees, firms need to provide them with the tools they need to succeed (Mathis \& Jackson 2009). Employee Performance includes quality and quantity of output, work attendance, regulatory nature and benefits including timeliness of service/production. Performance is related to quantity of output; fulfilling the deadlines, presence or absence on the job, effectiveness and efficiency of their works (Mathis \& Jackson 2009). The result of 
employees performance always depends on the behavior of them because the level of acceptance varies depending on individual believes and perceptions to contribute to organization's success (Aguinis, 2009).

\subsection{Ethical Leadership}

Ethical leaders will be the role models when they demonstrate integrity and set high ethical standards for themselves as well as others (Brown et al. 2005). Employees are thus more likely to follow and internalize the value driven behaviors of their role modeling ethical leaders (Brown and Treviñ 2006). Role modeling influences ethical behavior through motivational and informational means (Bandura 1977). Leaders as role models motivate ethical behavior by demonstrating the type of actions they want to promote and reward. In addition, leaders also serve as an informational guide for acceptable behaviors. Scholars also suggest that ethical leadership shapes follower behaviors through social exchange processes (Brown et al. 2005). Social exchange theory proposes that the norms of reciprocity or perceived obligation to return favors undergird many social relationships (Blau 1964; Gouldner 1960). According to social exchange theory, when followers perceive a leader as caring and concerned for their well-being, they feel obliged to reciprocate that leader's support. Building on these ideas, Brown et. Al, $(2005,2006)$ suggested that ethical leaders engender feelings of trust and fairness in their followers, and create an organizational environment where followers are more likely to reciprocate with beneficial organizational behavior.

Starratt (1991) defined ethical leadership as based on three interdependent dimensions of ethics (justice, critique and care) and later suggested that ethical leadership occurs through a meaningful process of learning (Starratt, 2004, 2012). There are many studies showing that there is a relationship between leadership and employee performance and most of them show positive results in this reagrd (Asree, et.al,2010; Walumbwa \& Hartnell, 2011; Siddique, 2012). Based on Asree, et.al, (2010), leadership competencies affect the employees' performance and it influences the firm's outcome. Leadership is applied to all as everyone have his or her own leadership skills. Leadership leads to higher employee satisfaction and by a good leadership style, employees will serve the customers better. Hence, the customer will be more satisfied with the services provided and it turns into customer loyalty. Besides, ethical leadership can also use the leader member exchange theory (LMX). The theory is the two-way approach between leaders and employees. The relationship between leaders and their employees will influence their work quality. A high quality relationship can be seen by trust, respect and loyalty from employees' perspective to both leader and the company (Erdogan \& Bauer, 2015). Studies on ethical leadership mainly focus on the last three dimensions of Rest's model and many limited ones work on ethical sensitivity as well, (eg. Riggio et al., 2010; Walumbwa et al., 2008; Yukl et al., 2013; Zhen et al., 2011). Yet, the findings point to the presence of a clear link between ethical sensitivity and ethical leadership. Developing ethical leadership requires the activation of ethical sensitivity in order to better exercise one's moral judgment (Langlois and Lapointe, 2010). Thus, based on previous research, many researchers hypothesized that the three dimensions of the ethical leadership questionnaire are significantly related to ethical sensitivity (Langlois and Lapointe, 2007, 
2009, 2010).

Kock and McNamara (2014) define employee engagement as a psychological state within which an employee connects and identifies at a personal level with their job and organization, resulting in retention and improved performance. Committed employees are able to discharge their duties satisfactorily leading to a high rate of customer satisfaction. Employees with a high sense of commitment and involvement are key factors to achieving organizational success. Creating commitment among employees however requires a thorough management program consisting of concrete management practices and personnel policies. In achieving competitive advantage, organizations must find a way of creating and harnessing the energy and enthusiasm individuals display on their respective jobs. This is achieved through the creation maintenance of a strong organizational culture, which is able to attract the kinds of people inclined to performing efficiently within the business environment (Macey et al., 2006)

Past researches on employee performance such as Jaramilloa, Mulki and Marshal, (2005) and Al-Ahmadi (2009) found several factors that can influence the employees' performance ranging from individual-related factors; organizational level factors as well as organizational environmental factors and we can see the footprints of ethical leadership in all of them. Thus, this study hypothesized the following:

H1: Ethical Leadership has a positive and significant relationship with employees' commitment

\subsection{Talent Management}

Academics and practitioners agree that talent management continues to be one of the priorities for organizations worldwide, since it can represent a source of sustainable competitive advantage in the highly dynamic and often uncertain market environment (Cascio \& Boudreau, 2016; Meyers \& Van Woerkom, 2014; Vaiman et al., 2012). Talent management can also be defined as one of those HRM-related "activities and processes that consist of the systematic identification of key positions contributing to the organization's sustainable competitive advantage, the development of a talent pool of high-potential and high-performing incumbents to fill these roles, development of a differentiated human resource architecture to facilitate filling these positions with competent incumbents, and to ensure their continued commitment to the organization" (Collings \& Mellahi, 2009).

However, in some organizations the talent may refer to the entire employee population (Lewis \& Heckman, 2006). Talent management as juxtaposed with talent as such relates to a set of processes concerning 'the strategic management of the flow of talents through an organization' (Iles et al. 2011). Talent management according to Mensah (2015) is the responsibility to identify an employee that have good skills and competences to keep up with the competitive and challenge in hotel industry. Many practices have been used by human resource departments to hire and find a talented employee so that they just need to polish them in order to provide a good performance. The goal of talent management is to maximize the talented employees and utilize them appropriately. 
Talent management activities and outputs may vary from one employee to the other, as the level of satisfactory is different but if the management becomes able to maximize the rewards, the output will be probable to appear through a social exchange theory approach (Jay \& Wittmann, 2008). Based on Cropanzano and Mitchell (2005) social exchange relationship evolves when management takes good care of its employees and it will benefit the firm in return. Advantageous and fair transactions between them strengthens their relationships, and these relationships produce effective work behavior and employee attitude which will result in higher performance.

Research studies (eg. Bates, 2004; Baumruk, 2004; Richman, 2006) have proven that the talent management can improve employee commitments, performance, profitability, customer satisfaction, retentions of employees and success of the organization. Thus, this study hypothesized the following:

H2: Talent Management has a positive and significant relationship with employees commitment

\subsection{Employee Commitments}

Employee commitment is a popular topic in management research because it acts like a bond that links employees to their organization and this can have a significant effect on their performance (Becker et al., 1996; Meyer et al., 2004; Rubin and Brody, 2011). Allen and Meyer (1997) define employee commitment as a psychological state that signifies the strength of an employee's relationship with his/her organization and reflects their intentions to maintain this relationship. Early research efforts focused on two aspects of employee commitment; attitudinal commitment, which centers on how employees think about their relationships with the organization; and behavioral commitment, which converges on how an individual may become locked into a particular organization (Mowday et al., 1979). Meyer and Allen (1993) extended this into a three-component model - affective (a desire), continuance (a need) and normative (an obligation) which influence outcomes such as, absenteeism, job performance and corporate citizenship. This conceptualization illustrates the complex nature of the employee commitment construct by helping to model employees' affiliation with, and disposition toward, their employer organizations.

Higher levels of employee commitment lead to a strong belief in and acceptance of an organization's goals and values; a strong will to exert best effort for the organization; and a strong desire to remain as a member of the organization (Becker et al., 1996; Meyer et al., 2004). Employee commitment is also a far better predictor of staff turnover than attendance, job satisfaction, individual- and group-level performance, employee loyalty and overall organizational effectiveness (Schneider et al., 2003). Employee commitment also help us to explain how an employee with a "positive job attitude creates a tendency to engage or contribute to desirable inputs into one's work role" (Sharma, P., Kong, T. T. C., \& Kingshott, R. P. (2016). Prior research finds a positive correlation between employee commitments and performance (Becker, et al., 1996). Satisfied employees generally have a more positive attitude that helps them to perform better (Mowday et al., 2013), and they are highly motivated, have good morale at work, and work more effectively and efficiently (Eskildsen 
and Dahlgaard, 2000). Hence, employee performance includes behaviors relevant to organizational goals that are under the control of individual employees (Rotundo, M., \& Sackett, P. R., 2002), it is reasonable to expect employees who have a stronger commitment to their jobs and to the organization, to work harder than those who do not (Robledo, M. A. (2001). Furthermore, study done by Mihardjo, Jermsittiparsert, Ahmed, Chankoson, and Hussain (2020) has proven the mediating role of employee commitment in the relationship between human resource practices and service recovery performance. Thus, this study hypothesized the following:

H3: Employees commitment has a positive relationship with employee performance

H4: Employees commitment mediates the relationship between ethical leadership and employee performance

H5: Employees commitment mediates the relationship between talent management and employee performance

\section{Methodology}

This section comprises the research design, type of study, data collection method, population, sampling method, unit of analysis, sample size and analysis techniques. The method of study is an important part of a research process, as it guides the study, whether in finding data or how the report is written (Coughlan, M., Cronin, P., \& Ryan, F. (2007). Quantitative research has been applied in this study as this study intended to see the impact of ethical leadership and talent management on employee performance and the mediating role of employee commitment. This research uses hypothesis testing to investigate the relationship between variables that is shown in the theoretical framework. 150 questionnaires are collected from one to three start hotels' front desk employees. The process of data collection started by determining the minimum needed sample size. As the study is a quantitative study, questionnaire is used. The researcher had adapted the questionnaire from previous researchers. Questionnaire has been distributed to the respondents manually. The size of the sample is based on Hair et. al (1995: 604) that mentioned that the best sample size is between 100-200. The Questioner encompasses of five section. The First section consists of demographic questions while the remaining four section include the items relating to the constructs as explained in Table 1.

Table 1. Inner part of the questionnaire

\begin{tabular}{|c|l|l|}
\hline Sections & Dimension & Reference \\
\hline Part A & Demographic respondent & $\begin{array}{l}\text { Lyse langlois, Claire Lapointe and Pierre Valois, } \\
\text { Astrid de Leeuw (2013) }\end{array}$ \\
\hline Part B & Ethical leadership & Yi Liu and Cecil (2014) \\
\hline Part C & Talent management & $\begin{array}{l}\text { Piyush Sharma, Titus Tak Chuen Kong and Russel } \\
\text { P.J. Kingshott (2016) }\end{array}$ \\
\hline Part D & Employee commitments & $\begin{array}{l}\text { Ernest Kissi, Odoi Ansah Asare, Kofi Agyekum } \\
\text { and Daniel Yamoah Agyemang (2019) }\end{array}$ \\
\hline Part E & Employee Performance & \\
\hline
\end{tabular}




\subsection{Theoretical Framework}

Figure one, depicts the research model by showing the link between ethical leadership, talent management and employee commitment and the mediating relationship between each variable.

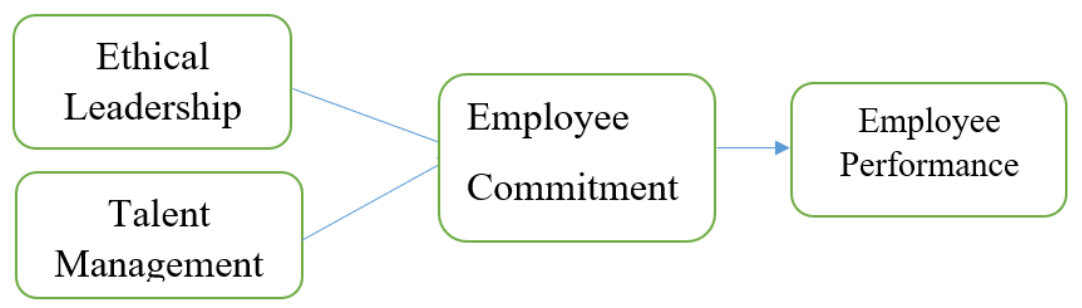

Figure 1. Theoretical Framework

\section{Results}

Table 2 tabulates the result on gender, age, location, education, frequency in dealing with customers, salary and the hotel ranking.

Table 2. Respondents' Demographic information

\begin{tabular}{|c|c|c|}
\hline Item & Frequency & Percentage \\
\hline $\begin{array}{c}\text { Gender } \\
\text { Male } \\
\text { Female } \\
\text { Total } \\
\end{array}$ & $\begin{array}{c}60 \\
90 \\
\mathbf{1 5 0}\end{array}$ & $\begin{array}{l}40 \% \\
60 \% \\
\mathbf{1 0 0}\end{array}$ \\
\hline $\begin{array}{l}\text { Age } \\
\text { Below } 18-19 \\
20-35 \text { years' old } \\
36-50 \text { years'old } \\
51-65 \text { years' old } \\
\text { Above } 65 \text { years' old } \\
\text { Total }\end{array}$ & $\begin{array}{c}32 \\
79 \\
33 \\
5 \\
1 \\
150\end{array}$ & $\begin{array}{l}21.3 \% \\
52.7 \% \\
22.0 \% \\
3.30 \% \\
0.70 \% \\
100 \%\end{array}$ \\
\hline $\begin{array}{l}\text { Location } \\
\text { Penang } \\
\text { Kuala Lumpur } \\
\text { Total }\end{array}$ & $\begin{array}{r}94 \\
56 \\
150\end{array}$ & $\begin{array}{c}62.7 \% \\
37.3 \% \\
\mathbf{1 0 0 . 0 \%}\end{array}$ \\
\hline $\begin{array}{l}\text { How frequent do you face } \\
\text { customer's daily task? } \\
\text { Daily } \\
\text { Weekly } \\
\text { Total } \\
\end{array}$ & $\begin{array}{c}78 \\
72 \\
\mathbf{1 5 0} \\
\end{array}$ & $\begin{array}{r}52.0 \% \\
48.0 \% \\
\mathbf{1 0 0 . 0 \%} \\
\end{array}$ \\
\hline $\begin{array}{l}\text { Degree of Education } \\
\text { SPM/STPM/Certificate } \\
\text { Diploma } \\
\text { Degree } \\
\text { Postgraduate } \\
\text { Total }\end{array}$ & $\begin{array}{c}5 \\
54 \\
83 \\
8 \\
150\end{array}$ & $\begin{array}{l}3.30 \% \\
36.0 \% \\
55.30 \% \\
5.30 \% \\
100.0 \%\end{array}$ \\
\hline $\begin{array}{l}\text { Salary } \\
\text { Less than RM1499 } \\
\text { RM1500-RM2499 } \\
\text { RM2500- RM4999 } \\
\text { More than RM5000 } \\
\text { Total }\end{array}$ & $\begin{array}{c}50 \\
72 \\
8 \\
20 \\
150\end{array}$ & $\begin{array}{l}33.0 \% \\
48.0 \% \\
5.30 \% \\
13.3 \% \\
\mathbf{1 0 0 . 0 \%} \\
\end{array}$ \\
\hline $\begin{array}{l}\text { Hotel Ranking } \\
\text { One Star } \\
\text { Two Stars } \\
\text { Three Stars } \\
\text { Total }\end{array}$ & $\begin{array}{c}9 \\
120 \\
21 \\
\mathbf{1 5 0}\end{array}$ & $\begin{array}{r}6.0 \% \\
80.0 \% \\
14.0 \% \\
\mathbf{1 0 0 . 0 \%} \\
\end{array}$ \\
\hline
\end{tabular}




\subsection{Hypothesis Testing}

On this section, the summary of results of our hypothesis testing is presented in table 3.

Table 3. Hypothesis testing

\begin{tabular}{|c|c|c|c|c|c|c|}
\hline $\begin{array}{l}\text { Influence } \quad \text { Between } \\
\text { Variables }\end{array}$ & $\begin{array}{l}\text { Original } \\
\text { Sample } \\
\text { (O) }\end{array}$ & $\begin{array}{l}\text { Sample } \\
\text { Mean } \\
\text { (M) } \\
\end{array}$ & $\begin{array}{l}\text { Standard } \\
\text { Deviation } \\
(\mathrm{STDEV}) \\
\end{array}$ & $\begin{array}{l}\text { T Statistics } \\
(|\mathrm{O} / \mathrm{STDEV}|)\end{array}$ & $\begin{array}{l}\mathrm{P} \\
\text { Values }\end{array}$ & Information \\
\hline $\begin{array}{l}\text { Employee Commitment -> } \\
\text { Employee Performance }\end{array}$ & 0.585 & 0.611 & 0.051 & 11.437 & 0.000 & Significant \\
\hline $\begin{array}{l}\text { Ethical Leadership } \quad \rightarrow \\
\text { Employee Commitment }\end{array}$ & -0.228 & -0.168 & 0.199 & 1.143 & 0.127 & $\begin{array}{c}\text { Not } \\
\text { significant }\end{array}$ \\
\hline $\begin{array}{l}\text { Ethical Leadership -> } \\
\text { Employee commitment_-> } \\
\text { Employee Performance }\end{array}$ & -0.133 & -0.100 & 0.120 & 1.108 & 0.134 & $\begin{array}{c}\text { Not } \\
\text { significant }\end{array}$ \\
\hline $\begin{array}{l}\text { Talent Management } \rightarrow> \\
\text { Employee Commitment }\end{array}$ & 0.747 & 0.721 & 0.162 & 4.624 & 0.000 & Significant \\
\hline $\begin{array}{l}\text { Talent Management -> } \\
\text { Employee Commitment_> } \\
\text { Employee Performance }\end{array}$ & 0.437 & 0.440 & 0.150 & 4.159 & 0.000 & Significant \\
\hline
\end{tabular}

The p-values less than 0.05 indicate a significant relationship.

\subsection{Instrument Validity and Reliability}

The result was measure by reflective measurement model (SMART PLS). Internal consistency reliability provides an estimate of the reliability based on inter-correlation of the observed indicators (Henseler, Hubona \& Ray, 2016). Cronbach's alpha, level of acceptance is $>0.7$ is means all the variable are acceptance because all of that are more than 0.7 that is ethical leadership is 0.942 , employees commitments is 0.846 , talent management is 0.939 and employee performance is 0.928 . The Composite Reliability (CR), level of acceptance is 0.7 and all our results are in this range. Discriminant validity is another way of measuring the validity of an indicator in a variable. It is done by comparing the square root of AVE coefficient of each latent variable with the correlation coefficient among other latent variables in the model. If the square root of AVE coefficient is greater than the correlation coefficient between variables in the model, then the indicators in the variable have good discriminant validity. Recommended AVE value must be greater than 0.50 . Figure 2 and table 4 shows the result for convergent validity and reliability and table 5 presents the result of discriminant validity calculation in this research. 


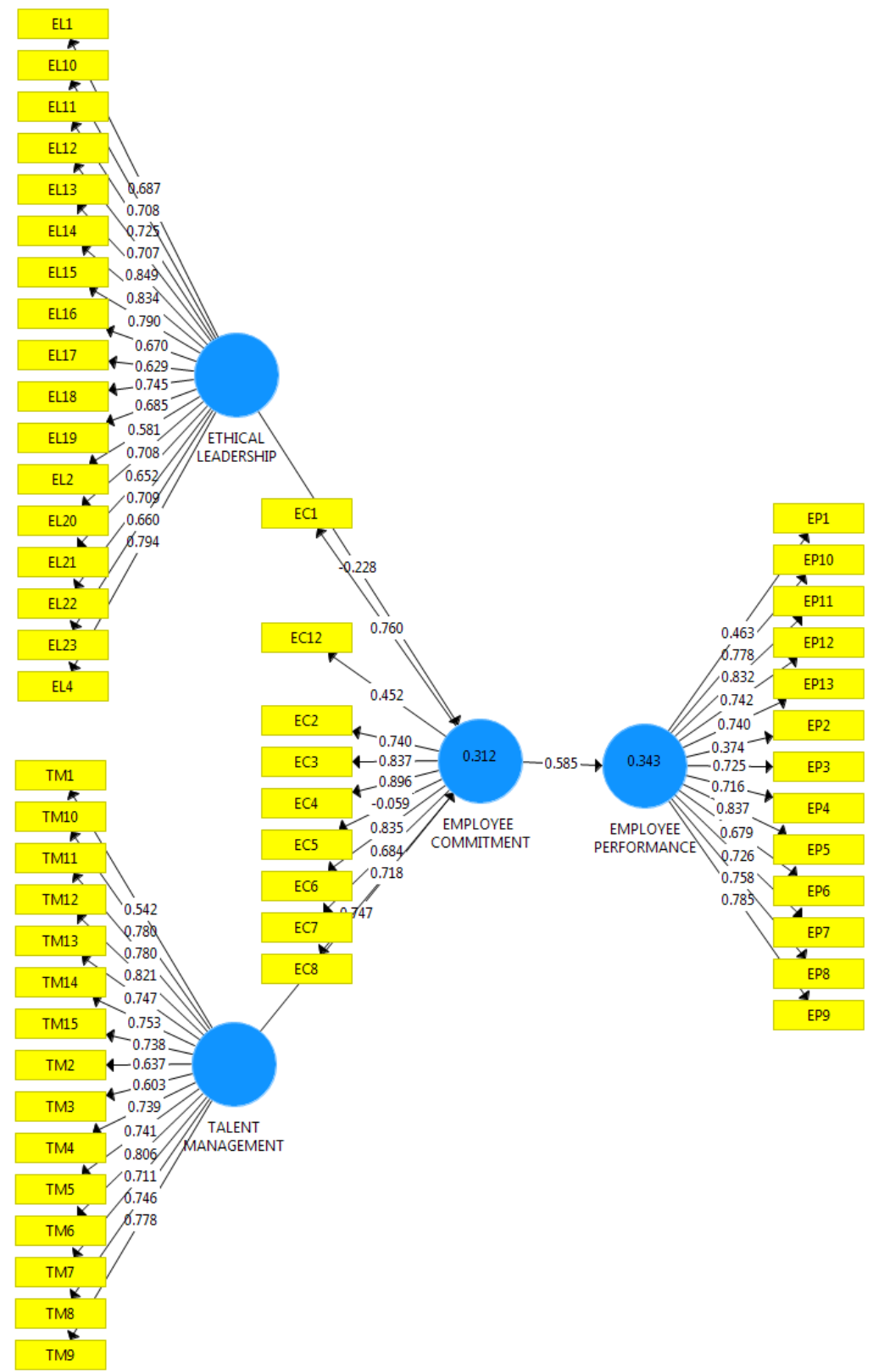

Figure 2. Research framework

Based on figure 2 and table 4, the results of convergent validity and reliability calculations show that the Factors Loading, Cronbachs Alpha, Rho_A, CR and AVE coefficient of each variable is greater than the correlation coefficient between the variables in the model. It can be concluded that the indicators in the variable have good discriminant validity. This means that the value of AVE for talent management variable of 0.536 is greater than the AVE between with other variables, i.e. $0.514,0.502$ and 0.513 .

Based on Table 5, the results of discriminant validity calculations show that the square root of AVE coefficient of each variable is greater than the correlation coefficient between the variables in the model. It can be concluded that the indicators in the variable have good discriminant validity. This means that the value of AVE for talent management variable of 0.984 is greater than the correlation coefficient between employee performance variables 
with other variables, i.e. $0.873,0.732$ and 0.548 .

Table 4. Convergent Validity and Reliability

\begin{tabular}{|c|c|c|c|c|c|c|}
\hline Variables & Item & $\begin{array}{l}\text { Factors } \\
\text { Loading }\end{array}$ & $\begin{array}{c}\text { Cronbach } \\
\text { S Alpha }\end{array}$ & $\mathrm{Rho}_{\text {A }}$ & CR & AVE \\
\hline $\begin{array}{l}\text { Ethical } \\
\text { leadership }\end{array}$ & $\begin{array}{c}\text { EL1 } \\
\text { EL10 } \\
\text { EL11 } \\
\text { EL12 } \\
\text { EL13 } \\
\text { EL14 } \\
\text { EL15 } \\
\text { EL16 } \\
\text { EL17 } \\
\text { EL18 } \\
\text { EL19 } \\
\text { EL2 } \\
\text { EL20 } \\
\text { EL21 } \\
\text { EL22 } \\
\text { EL23 } \\
\text { EL4 } \\
\end{array}$ & $\begin{array}{l}0.687 \\
0.708 \\
0.725 \\
0.707 \\
0.849 \\
0.834 \\
0.790 \\
0.670 \\
0.629 \\
0.745 \\
0.685 \\
0.581 \\
0.708 \\
0.652 \\
0.709 \\
0.660 \\
0.794 \\
\end{array}$ & 0.942 & 0.958 & 0.947 & 0.514 \\
\hline $\begin{array}{l}\text { Employee } \\
\text { commitments }\end{array}$ & $\begin{array}{c}\text { EC1 } \\
\text { EC12 } \\
\text { EC2 } \\
\text { EC3 } \\
\text { EC4 } \\
\text { EC5 } \\
\text { EC6 } \\
\text { EC7 } \\
\text { EC8 } \\
\end{array}$ & $\begin{array}{l}0.760 \\
0.452 \\
0.740 \\
0.837 \\
0.896 \\
-0.059 \\
0.835 \\
0.684 \\
0.718 \\
\end{array}$ & 0.846 & 0.886 & 0.885 & 0.502 \\
\hline $\begin{array}{l}\text { Talent } \\
\text { Management }\end{array}$ & $\begin{array}{l}\text { TM1 } \\
\text { TM10 } \\
\text { TM11 } \\
\text { TM12 } \\
\text { TM13 } \\
\text { TM14 } \\
\text { TM15 } \\
\text { TM2 } \\
\text { TM3 } \\
\text { TM4 } \\
\text { TM5 } \\
\text { TM6 } \\
\text { TM7 } \\
\text { TM8 } \\
\text { TM9 }\end{array}$ & $\begin{array}{l}0.542 \\
0.780 \\
0.780 \\
0.821 \\
0.747 \\
0.753 \\
0.738 \\
0.637 \\
0.603 \\
0.739 \\
0.741 \\
0.806 \\
0.711 \\
0.746 \\
0.778\end{array}$ & 0.939 & 0.951 & 0.945 & 0.536 \\
\hline $\begin{array}{l}\text { Employee } \\
\text { Performance }\end{array}$ & $\begin{array}{c}\text { EP1 } \\
\text { EP10 } \\
\text { EP11 } \\
\text { EP12 } \\
\text { EP13 } \\
\text { EP2 } \\
\text { EP3 } \\
\text { EP4 } \\
\text { EP5 } \\
\text { EP6 } \\
\text { EP7 } \\
\text { EP8 } \\
\text { EP9 } \\
\end{array}$ & $\begin{array}{l}0.463 \\
0.778 \\
0.832 \\
0.742 \\
0.740 \\
0.374 \\
0.725 \\
0.716 \\
0.837 \\
0.679 \\
0.726 \\
0.758 \\
0.785 \\
\end{array}$ & 0.928 & 0.932 & 0.930 & 0.513 \\
\hline
\end{tabular}


Table 5. Discriminant validity

\begin{tabular}{|l|l|l|l|l|}
\hline & $\begin{array}{l}\text { Employee } \\
\text { Commitment }\end{array}$ & $\begin{array}{l}\text { Employee } \\
\text { Performance }\end{array}$ & $\begin{array}{l}\text { Ethical } \\
\text { Leadership_ }\end{array}$ & $\begin{array}{l}\text { Talent } \\
\text { Management }\end{array}$ \\
\hline $\begin{array}{l}\text { Employee } \\
\text { Commitment }\end{array}$ & 0.708 & & & \\
\hline $\begin{array}{l}\text { Employee } \\
\text { Performance }\end{array}$ & 0.585 & 0.716 & & \\
\hline Ethical Leadership & 0.425 & 0.847 & 0.717 & \\
\hline Talent Management & 0.548 & 0.984 & 0.873 & 0.732 \\
\hline
\end{tabular}

\section{Discussion and Conclusion}

\subsection{Research Findings}

Based on the research findings, the research shows that the ethical leadership does not have significant relationship with employee commitments. Besides that, employee commitment does not mediate the relationship between ethical leadership and employee performance. This happened because the employee commitments have been running in such a way without requiring the role of ethical leadership value. Meanwhile, employee practice self-leadership among them due to the engagement and talent management, without the need to be advised or supervised by the leader.

Next, the talent management has a positive and significant relationship with employee commitments. Therefore, the talent management in employee was higher as stated in the survey which is, "in my organization, low-level employee with similar competencies/abilities are grouped into a unit/team/ pool (i.e., pools of talents" and "In my organization, projects are undertaken by forming a team of low-level employee (talented pools) who have been selected from groups with similar talents (front desk employee)". Besides, employee commitments mediates the relationship between talent management and employee performance. This findings reflect on the condition of employees in 1-star to 3-stars hotel, where the role of the talent management will be able to improve employee commitments

\subsection{Research Implications}

This study provides several managerial implications and offers hotels management a framework by which to understand how front desk employees' performance is affected by ethical leadership and talent management through employee commitment. The research shows that it is important for the management of one to three-stars hotel to consider talent management in enhancing their front desk employees' performance. Hotel management must create a good talent management programs by incorporating the element that encourage employee engagement. The research contributes to the literature in several ways. First, in response to calls for more research into other factors that influences employee performance in other industries, particularly in hotel industry. Secondly, few studies have done on the mediating effect of employee commitment, thus the result of the study has proven the mediating effect of employee commitment. Thirdly, the findings of the study add to the body of knowledge in human resource and human capital management. 


\subsection{Limitations of Research}

The integration of variables in this research still insufficient to generalize in all research relate to the four variables. In addition, this research mainly focused on Penang and Kuala Lumpur area. This research only involves 1-star to 3-stars hotel and not focus on the non-star hotel or the high-end hotels. The research also needs to expand to other tourist attraction in Malaysia.

\subsection{Theoretical Recommendations}

For theoretical recommendations, other variables such as employee engagement, individual personality, other leadership styles and procedural justice should be factor in when it comes to test the employee performance in the hotel industries. Besides social exchange theory and leader member exchange, future study should also incorporate self-determination theory in investigating factors that lead to employee performance in the hotel industry.

\subsection{Practical Recommendations}

The research should be conducted in other unrated hotels. Hotels management in one to three stars hotel should have given more attentions to the employee talent management. Although the talent management is more impactful in influencing employee performance and commitments, there are still other factors that need to be considered. In addition, the hotel management is advisable to pay more attention related to the employee commitment which reflected by focus on work, paying attention to work, happiness in work, fostering sense of ownership and respect of other employees in the hotels. Other than that, for the management of the hotel, they should be able to maintain the employee performance in executing the work by collaborating, coordinating and communicating well. The role of employees in taking the initiative to help the problem will be able to open to criticism, be able to learn from mistakes, and be able to prioritize the guest/client interests and satisfaction. The results of this research shows that talent management is more effective than ethical leadership directly and indirectly in influencing employee performance through the mediating role of employee commitment.

\section{References}

Aguinis, H. (2009). Performance management. Upper Saddle River, NJ: Pearson/Prentice Hall.

Ahmed, I., Sultana, I., Paul, S. K., \& Azeem, A. (2013). Employee performance evaluation: a fuzzy approach. International Journal of Productivity and Performance Management.

Anitha, J. (2014). Determinants of employee engagement and their impact on employee performance. International journal of productivity and performance management.

Asree, S., Zain, M., \& Razalli, M. R. (2010). Influence of leadership competency and organizational culture on responsiveness and performance of firms. International Journal of Contemporary hospitality management.

Bandura, A., \& Walters, R. H. (1977). Social learning theory (Vol. 1). Englewood Cliffs, NJ: Prentice-hall. 


\section{Macrothink}

International Journal of Human Resource Studies

ISSN 2162-3058 2020, Vol. 10, No. 3

Bates, S. (2004). Getting engaged. HR magazine, 49(2), 44-51.

Baumruk, R., \& Marusarz, T. (2004). Employee Engagement: Insights into why it matters and what you can do about it. Hewitt Associates LLC.

Becker, T. E., Billings, R. S., Eveleth, D. M., \& Gilbert, N. L. (1996). Foci and bases of employee commitment: Implications for job performance. Academy of management journal, $39(2), 464-482$.

Blau, P. M. (1964). 1964 Exchange and power in social life. New York: Wiley.

Brown, M. E. (2007). Misconceptions of ethical leadership: How to avoid potential pitfalls. Organizational Dynamics.

Brown, M. E., \& Trevino, L. K. (2006). Ethical leadership: A review and future directions. Leadership Quarterly, 17, 595-616.

Burlea-Schiopoiu, A., \& Mihai, L. S. (2019). An Integrated Framework on the Sustainability of SMEs. Sustainability, 11(21), 6026.

Cascio, W. F., \& Boudreau, J. W. (2016). The search for global competence: From international HR to talent management. Journal of World Business, 51(1), 103-114.

Cappelli, P. (2009). Talent on demand-managing talent in an age of uncertainty. Strategic Direction, 25(3), pp. 5-7.

Cheng, B. L., Gan, C. C., Imrie, B. C., \& Mansori, S. (2019). Service recovery, customer satisfaction and customer loyalty: evidence from Malaysia's hotel industry. International Journal of Quality and Service Sciences.

Collings, D., \& Mellahi, K., (2009), Strategic Talent Management; a review and research agenda. Human Resource Management Review, 19(4), 304-313.

Coughlan, M., Cronin, P., \& Ryan, F. (2007). Step-by-step guide to critiquing research. Part 1: quantitative research. British journal of nursing, 16(11), 658-663.

Cropanzano, R., \& Mitchell, M. (2005). Social Exchange Theory: An Interdisciplinary Review. Journal of Management, 874-894.

Dernovsek, D. (2008), "Creating highly engaged and committed employee starts at the top and ends at the bottom line credit union”, Credit Union National Association, Inc., May

Dessler, G. (2005), The Role of Human Resource Information System in the Process of Manpower Activities. Human Resource Management, 5(6), 1.

Ellis, C. M., \& Sorensen, A. (2007). Assessing employee engagement: the key to improving productivity. Perspectives, 15(1), 1-9.

Erdogan, B., \& Bauer, T. (2015). Leader-Member Exchange Theory. International Encyclopedia of the Social and Behavioral Sciences, 13, 1-6. 
Kissi, E., Asare, O. A., Agyekum, K., Agyemang, D. Y., \& Labaran, M. (2019). Ascertaining the interaction effects among organisational citizenship behaviour, work overload and employees' performance in the Ghanaian construction industry. International Journal of Productivity and Performance Management .

Eskildsen, J. K., \& Dahlgaard, J. J. (2000). A causal model for employee satisfaction. Total quality management, 11(8), 1081-1094.

Evans, J. R., \& Lindsay, W. M. (2013). Managing for quality and performance excellence . Cengage Learning.

Farndale, E., Scullion, H., \& Sparrow, P. (2010). The role of the corporate HR function in global talent management. Journal of World Business, 45(2), 161-168.

Gallup, I. (2013). State of the American workplace: Employee engagement insights for US business leaders. Retrieved from Washington, DC: http://www. gallup. Com

Gay, L. R., Mills, G. E., \& Airasian, P. W. (1976). Educational research: Competencies for analysis and application. Columbus, $\mathrm{OH}$ : Merrill.

Gouldner, A. W. (1960). The norm of reciprocity: A preliminary statement. American sociological review, 161-178.

Hair, J. F., Anderson, R. E., Tatham, R. L., \& Black, W. C. (1995). Multivariate data analysis, 4th Edition, Prentice Hall, New Jersey.

Hassan, S., Mahsud, R., Yukl, G., \& Prussia, G. E. (2013). Ethical and empowering leadership and leader effectiveness. Journal of Managerial Psychology.

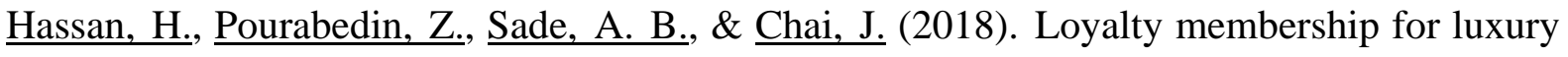
hotels in Malaysia. International Journal of Tourism Cities, 4(2), 179-193.

Henseler, J., Hubona, G., \& Ray, P. A. (2016). Using PLS path modeling in new technology research: updated guidelines. Industrial management $\&$ data systems.

Huselid, M. A., \& Becker, B. E. (1997, August). The impact high performance work systems, implementation effectiveness, and alignment with strategy on shareholder wealth. In Academy of Management Proceedings (Vol. 1997, No. 1, pp. 144-148). Briarcliff Manor, NY 10510: Academy of Management.

Iles, P., Chuai, X., \& Preece, D., (2010), Talent Management and HRM in multinational companies in Beijing: definitions, differences and drivers. Journal of World Business, 45(2), 179-189.

Jaramillo, F., Mulki, J. P., \& Marshall, G. W. (2005). A meta-analysis of the relationship between organizational commitment and salesperson job performance: 25 years of research. Journal of Business Research, 58, 705-714.

Jay, C., \& Wittmann, C. (2008). Social Exchange Theory and Research on Business-to Business Relational Exchange. Journal of Business-to-Business Marketing, 1-36. 


\section{Macrothink}

International Journal of Human Resource Studies

ISSN 2162-3058 2020, Vol. 10, No. 3

Kara, S. (2017). Malaysia's Hotel Industry and link analysis: Tabung Haji Hotel Sample, Turkey: Altinbas University.

KocK, R., \& McNamara, K. (2014). Debunking talent retention myths: on the cover-feature. HR Future, 7(1), 36-37.

Khatri, P. (2010). Talent Management in HR. Journal of Management and Strategy,1, 39-46.

Leedy, P. D. (1993). Practical Research, Planning and Design, Columbus: Merill.

Langlois, L., Lapointe, C., Valois, P., \& de Leeuw, A. (2014). Development and validity of the ethical leadership questionnaire. Journal of Educational Administration .

Macey, W. H., Schneider, B., \& Kraut, A. I. (2006). Employee experiences and customer satisfaction: Toward a framework for survey design with a focus on service climate. Getting action from organizational surveys, 53-75.

McBain, R. (2007). The practice of engagement: research into current employee engagement practice. Strategic HR Review, 6(6), 16-19.

Mensah, J. (2015). A coalesced framework of talent management and employee performance: for further research and practice. International Journal of Productivity and Performance Management, 64(4), 544-566.

Meyer, J. P., \& Allen, N. J. (1997). Commitment in the workplace: Theory, research, and application. Sage.

Meyer, J. P., \& Allen, N. J. (1991). A three-component conceptualization of organizational commitment. Human Resource Management Review, 1(1), 61-89.

Meyer, J. P., Allen, N. J., \& Smith, C. A. (1993). Commitment to organizations and occupations: Extension and test of a three-component conceptualization. Journal of applied psychology, 78(4), 538.

Meyers, M. C., \& Van Woerkom, M. (2014). The influence of underlying philosophies on talent management: Theory, implications for practice, and research agenda. Journal of World Business, 49(2), 192-203.

Mihardjo, L. W., Jermsittiparsert, K., Ahmed, U., Chankoson, T., \& Hussain, H. I. (2020). Impact of key HR practices (human capital, training and rewards) on service recovery performance with mediating role of employee commitment of the Takaful industry of the Southeast Asian region. Education+ Training .

Mukherjee, D., Lahiri, S., \& Billing, T. K. (2012). Leading virtual teams: how do social,cognitive, and behavioral capabilities matter? Management Decision, 273-290.

Mowday, R. T., Porter, L. W., \& Steers, R. M. (2013). Employee-organization linkages: The psychology of commitment, absenteeism, and turnover. Academic press. 


\section{Ml Macrothink}

International Journal of Human Resource Studies

ISSN 2162-3058 2020, Vol. 10, No. 3

Nadiri, H., \& Tanova, C. (2010). An investigation of the role of justice in turnover intentions, job satisfaction, and organizational citizenship behavior in hospitality industry. International Journal of Hospitality Management, 29(1), 33-41.

Nejati, M., Salamzadeh, Y., \& Loke, C. K. (2019). Can ethical leaders drive employees' CSR engagement?. Social Responsibility Journal.

Noraini, I. (2010), Penyelidikan dalam Pendidikan. McGraw-Hill (Malaysia) Sdn. Bhd.

Pandita, D., \& Ray, S. (2018). Talent management and employee engagement-a meta-analysis of their impact on talent retention. Industrial and Commercial Training.

Patton, M. Q. (2002). Two decades of developments in qualitative inquiry: A personal, experiential perspective. Qualitative social work, 1(3), 261-283.

Peng, J., Li, D., Zhang, Z., Tian, Y., Miao, D., Xiao, W., \& Zhang, J. (2016). How can core self-evaluations influence job burnout? The key roles of organizational commitment and job satisfaction. Journal of health psychology, 21(1), 50-59.

Perrin, T. (2003). Working today: understanding what drives employee engagement. The 2003 Towers Perrin Talent Report, US report, City Lake, available at: www.towersperrin.com/tp/getwebcachedoc?Webc=HRS USA/2003/200309/Talent_2003.pdf (accessed June 9, 2020)

Resick, C. J., Hanges, P. J., Dickson, M. W., \& Mitchelson, J. K. (2006). A cross-cultural examination of the endorsement of ethical leadership. Journal of Business Ethics, 63(4), 345-359.

Richman, A. (2006). Everyone wants an engaged workforce how can you create it. Workspan, 49(1), 36-39.

Riggio, R. E., Zhu, W., Reina, C., \& Maroosis, J. A. (2010). Virtue-based measurement of ethical leadership: The Leadership Virtues Questionnaire. Consulting Psychology Journal: Practice and Research, 62(4), 235.

Robertson, I. T., \& Birch, A. J. (2010). The role of psychological well-being in employee engagement", Proceedings of the British Psychological Society Occupational Psychology Conference, Brighton.

Robledo, M. A. (2001). Measuring and managing service quality: integrating customer expectations. Managing Service Quality: An International Journal.

Rubin, B. A., \& Brody, C. J. (2011). Operationalizing management citizenship behavior and testing its impact on employee commitment, satisfaction, and mental health. Work and occupations, 38(4), 465-499.

Rotundo, M., \& Sackett, P. R. (2002). The relative importance of task, citizenship, and counterproductive performance to global ratings of job performance: A policy-capturing approach. Journal of applied psychology, 87(1), 66. 
Piyush, S., Titus, T., Chuen, K., \& Russel, P. J. K. (2016). Internal service quality as adriver of employee satisfaction, commitment and performance. Journal of Service Management, 27(5), 773-797.

Sabir, M. S., Iqbal, J. J., Rehman, K. U., Shah, K. A., \& Yameen, M. (2012), Impact of corporate ethical values on ethical leadership and employee performance. International Journal of Business and Social Science, 3(2), 163-171.

Schneider, B., Hanges, P. J., Smith, D. B., \& Salvaggio, A. N. (2003). Which comes first: employee attitudes or organizational financial and market performance?. Journal of applied psychology, 88(5), 836.

Scullion, H., Collings, D. G., \& Vaiman, V. (2016). Guest editorial: Strategic talent management. Employee Relations Today, 38(1), 1-5.

Sharma, P., Kong, T. T. C., \& Kingshott, R. P. (2016). Internal service quality as a driver of employee satisfaction, commitment and performance. Journal of service management.

Siddique, C. (2012). Knowledge management initiatives in the United Arab Emirates: a baseline study. Journal of Knowledge Management, 16(5), 702-703.

Sparrow, P., Scullion, H., \& Tarique, I. (2014). Strategic talent management: Contemporary issues in international context. Cambridge: Cambridge University Press.

Starratt, R. J. (1991). Building an ethical school: A theory for practice in educational leadership. Educational administration quarterly, 27(2), 185-202.

Starratt, R. J. (2004). Ethical leadership (Vol. 8). Jossey-Bass.

Thunnissen, M., Boselie, P., \& Fruytier, B. (2013). Talent management and the relevance of context: Towards a pluralistic approach. Human Resource Management Review, 23(4), 326-336.

\section{UNWTO (2017). UNWTO Tourism Annual Report 2016, UNWTO}

Vaiman, V., Collings, D., \& Scullion, H. (2012). Global talent management: trends, challenges, and opportunities. Management Decision, 50(5), 925-941.

Walumbwa, F. O., Avolio, B. J., Gardner, W. L., Wernsing, T. S., \& Peterson, S. J. (2008). Authentic leadership: Development and validation of a theory-based measure. Journal of management, 34(1), 89-126.

Walumbwa, F. O., \& Hartnell, C. A. (2011). Understanding transformational leadership-employee performance links: The role of relational identification and self-efficacy. Journal of occupational and organizational psychology, 84(1), 153-172.

Walumbwa, F. O., \& Shaubroeck, J. (2009), Leader personality traits and employee voice behaviour: mediating roles of ethical leadership and work group psychological safety. Journal of Applied Psychology, 94(5), 1275-1286. 


\section{Macrothink}

International Journal of Human Resource Studies

ISSN 2162-3058 2020, Vol. 10, No. 3

Wang, H., Law, K., Hackett, R. D., Wang,, D., \& Chen, Z. X., (2005), Leader-member exchange as a mediator of the relationship between transformational leadership and followers performance and organizational citizenship behaviour Academy of Management Journal, 48, 420-32.

Widani, I. A., Widyawati, S. R., \& Alexandra, C. (2019). The employee engagement and OCB as mediating on employee performance, International Journal of Productivity and Performance Management, 1741-0401.

Wright, P. M., \& Snell, S. A., (2009), Human Resources,Organizational Resources. and Capabilities. The Routledge Companion to Strategic Human Resources Management, 345-356.

Yi, L., \& Cecil. (2014), The importance of talent management: a study of Chinese organisations. Journal of Chinese Economic and Foreign Trade Studies,7(3), 153-172.

Zhang, Z., \& Peterson, S. J. (2011). Advice networks in teams: The role of transformational leadership and members' core self-evaluations. Journal of Applied Psychology, 96(5), 1004.

Zehir, C., \& Erdogan, E. (2011). The association between organizational silence and ethical leadership through employee performance. Procedia- Social and Behavioral Science, 24, 1389-1404.

\section{Copyright Disclaimer}

Copyright for this article is retained by the author(s), with first publication rights granted to the journal.

This is an open-access article distributed under the terms and conditions of the Creative Commons Attribution license (http://creativecommons.org/licenses/by/4.0/). 